\title{
Experiences and Daily Life Attitudes of Women With Severe Mental Disorders: Integrative Review of Associated Factors
}

\author{
Juliana Reale Caçapava Rodolpho ${ }^{\mathrm{a}, *}$, Luiza Akiko Komura Hoga ${ }^{\mathrm{a}}$, Jéssica Reis-Queiroz ${ }^{\mathrm{a}}$, Milena Temer Jamas ${ }^{\mathrm{b}}$ \\ a University of São Paulo, School of Nursing, Cerqueira Cesar, São Paulo, SP, Brazil \\ b São Paulo State University, Faculty of Medicine of Botucatu, Department of Nursing
}

\section{A B S T R A C T}

Objective: The objective is to identify the factors that influence the experiences and daily life attitudes of women with severe mental disorders (SMD).

Method: A search for studies published from 2000 to 2014 was conducted in electronic databases. All relevant primary studies were screened using integrative methods. Findings were synthesized thereafter.

Results: Fifteen articles were included. A total of 21 factors were identified as being associated with experiences and daily life attitudes of women with SMD. These factors consisted of the following five categories: strengths and limitations regarding self-care behavior and healthcare delivery, unmet healthcare needs, psychosocial vulnerabilities underlying SMD, gains and challenges of motherhood, and adoption of coping strategies.

Conclusions: Healthcare providers can greatly contribute to improving the quality of healthcare for women with SMD, but several barriers need to be overcome.

(c) 2015 Elsevier Inc. All rights reserved.

Millions of people are affected by mental disorders (MD) worldwide [World Health Organization (WHO, 2013)]. The burden of disease and disability attributable to MD in the affected individuals and their family members is great (WHO, 2010a). Severe mental disorders (SMD) result in serious functional impairments, which substantially interferes with or limits one or more major life activities. SMD are defined as mental, behavioral, or emotional disorders, excluding developmental and substance disorders. SMD include, but are not limited to, disorders such as schizophrenia, schizoaffective disorders, bipolar affective disorder, obsessive-compulsive disorder, posttraumatic stress disorder, and major depression (U.S. Department of Health and Human Services, 2012).

Gender differences have an impact on mental health and the experience and course of women's MD (Andrade, Viana, \& Silveira, 2006; Judd, Armstrong, \& Kulkarni, 2009). A range of studies have been indicated that women are disproportionately affected by mental health problems and that their vulnerability is closely associated with domestic violence and sexual abuse, socioeconomic disadvantage, low income and income inequality, low or subordinate social status. Pressures created by their multiple roles as wife, mother, and carer of elderly relatives also need to be taken into account to understand the risk factors for mental illness and the consequences for women and their families (McKay, 2010; WHO, 2006, 2013).

\footnotetext{
* Corresponding Author: Juliana Reale Caçapava Rodolfo, RN, MSN, Nurse, PhD Candidate, University of São Paulo, School of Nursing, 419 Avenida Dr. Enéas Carvalho de Aguiar ave, Cerqueira Cesar, 05403-000, São Paulo, SP, Brazil.

E-mail addresses: jureale@usp.br (J.R.C. Rodolpho), kikatuca@usp.br (L.A.K. Hoga), jessicagreis@usp.br (J. Reis-Queiroz), milena14enf@yahoo.com.br (M.T. Jamas).
}

In this context, women's mental health has been recognized as a serious public health (Andrade et al., 2006; Davidson, 2012). Depressive disorders account for close to $41.9 \%$ of the disability from neuropsychiatric disorders among women compared to $29.3 \%$ among men globally. Women are at increased risk of violence from an intimate and are over represented among the population of highly comorbid people who carry the major burden of psychiatric disorder (WHO, 2006).

Evidence also suggests that stressful life events and reproductive health problems are closely associated with SMD. SMD increases the risks of problems related to sexual behaviors (Soares \& Carvalho, 2009; UNFPA, 2008). Gender-related health concerns, such as sexually transmitted diseases, unplanned pregnancies, lack of screening tests for breast and cervical cancer more strongly impact women affected by SMD (Lyon \& Parker, 2003; UNFPA, 2008). Negative experiences suffered by women during pregnancy, childbirth, puerperium, and motherhood increase their susceptibility to MD (Birch, Lavender, \& Cupitt, 2005). MD following childbirth and motherhood, including postpartum depression, is estimated to affect about $13 \%$ of women within 1 year of delivery (WHO, 2006).

In Latin American and Caribbean countries, the prevalence of SMD among women has been high (Kohn \& Rodriguez, 2009). Data from selected epidemiological studies collated by Kohn and Rodriguez, (2009) showed that the prevalence of SMD in women was $12.6 \%$ for major depression, $5.5 \%$. While more than $80 \%$ of the burden provoked by MD worldwide occurs in people living in low- and middle-income countries, a significant gap is recognized in research to measure and describe the problem, and in strategies, policies and programs to prevent mental disorders in developing countries (Collins et al., 2011; WHO, 2013, 2014). 
Less attention is paid to the psychiatric care of women suffering with SMD. Their values, preferences, and personal care needs are not adequately identified, approached, and considered in the provision of healthcare (Drake, O'Neal, \& Wallach, 2008). Such women are not recognized as people requiring special support, especially in developing countries. Consequently, they are stigmatized and suffer discrimination in mental healthcare facilities, and adequate treatment is not provided to them (McKay, 2010; WHO, 2013). Women with SMD often have their human rights violated, and they may live in inadequate hygienic conditions, suffering physical and sexual abuse, and receive harmful and degrading treatments in healthcare settings (WHO, 2013). They may underreport mental illness symptoms because of fear and stigma (Davidson, 2012).

Sensitive strategies to address the needs of these women should be developed, implemented, and evaluated (Borba et al., 2011; DiazCaneja \& Johnson, 2004; McKay, 2010). Data derived from empirical studies are considered to be critical elements to support appropriate planning, implementation, and evaluation of mental health public policies (WHO, 2013). An integrative review (IR) of the experiences and daily life attitudes of women with SMD and the factors associated may contribute to improve the quality of healthcare. IR has an international reputation in evidence-based practice. It is a type of review that can go beyond the analysis and synthesis of findings from primary studies, and allows exploiting other research dimensions, in order to integrate individual and contextual questions to solidify the complex aspects of healthcare (Soares et al., 2014).

\section{REVIEW QUESTION AND GOALS}

The goal of this IR was to identify the factors influencing the experiences and daily life attitudes of women with SMD.

\section{METHOD}

This research followed the integrative, systematic review process, which was considered the most appropriate for the review question. The IR is a broad type of research review method that allows for inclusion of empirical studies with diverse methodologies. It adheres to a systematic process to summarize and synthesize findings, with the intent to more fully understand a particular phenomenon (Whittemore \& Knafl, 2005). The five-stage integrative review of the concept of integration proposed by Whittemore (2005) was used: (a) problem identification; (b) literature search; (c) data evaluation; (d) data analysis; and (d) presentation of the results. To direct the systematic literature search, a written search protocol was prepared.

\section{Literature Search}

Primary studies available in English, French, Portuguese and Spanish were included in this IR. This IR literature search was limited to studies published from January 1, 2000, to July 1, 2014 in order to select recent publications that may have more relevance to contemporary women's mental health issues in the provision of treatment and care than earlier studies. This limit was also established taking into account the WHO report 'Mental Health: New understanding, New Hope', published in 2001 (WHO, 2001). This report summarized the current knowledge on mental disorders and highlighted the need of transforming the understanding and treatment of MD, through comprehensive mental healthcare based on community-based mental health services.

The search strategy and subsequent decisions about inclusion and exclusion of studies were shaped by the review question (Soares et al., 2014). The following databases were explored: CINAHL, PubMed, PsycINFO, Sociological Abstracts, The Cochrane Library, The Joanna Briggs Institute (JBI) Database of Systematic Reviews and Implementation Reports, Scopus, Lilacs, Scielo, IBECS, and BDENF.
A search of the secondary databases was previously conducted to establish whether a review about the questions in this review has already been conducted. The JBI Database of Systematic Reviews and Implementation Reports and the Cochrane Library databases were examined to verify whether a systematic review about this theme had been published or was in progress. No similar systematic review protocols or final reports were identified.

The initial search strategy was performed through conjoined subject headings using the following Boolean strategy: 'attitude' or 'attitudes' or 'life experiences' or 'experiences' or 'needs' and 'mental disorders' or 'mentally ill persons' or 'mental health' and 'females' or 'women', and keywords 'attitude*' or 'experience*' or 'life experience*' or 'need*'. The reference lists of the included studies were also hand-searched.

The inclusion criteria were quantitative, qualitative, and mixedmethod empirical studies published in peer-reviewed journals. This review considered studies that include the following outcome measures: all aspects related both directly and indirectly to the factors influencing the experiences and daily life attitudes of women with an SMD diagnosis.

The exclusion criteria of the study samples were as follows: studies consisting of women less than 18 years old, and women without a diagnosis of SMD. Articles which studied women diagnosed with an SMD with its onset in the puerperium were excluded. If a paper was found to focus on the opinions of women as well as their formal and informal network members, only the women's perspectives were considered.

A total of 15 empirical studies fulfilled the eligibility criteria and were included in this IR (Table 1). The search process is summarized in Fig. 1.

In Table 1, the data extracted from empirical studies are reported.

\section{Data Evaluation}

The methodological quality of the empirical studies was independently assessed by two reviewers using the Framework for Research Critique (Caldwell, Henshaw, \& Taylor, 2011). This framework is an instrument consisting of 17 items, which include areas common to both qualitative and quantitative approaches plus areas that are specific to each research methodology.

The appraisal of mixed-methods studies addressed both the qualitative and quantitative features of this instrument. Items answered with 'yes' or 'no' included the following criteria: the comprehensiveness of the literature review, statement of philosophical background, rationale for undertaking research, appropriateness of research design and sample, validity, reliability or auditability of data collection, credibility/ability to confirm the data analysis, appropriateness of how the results were presented, comprehensiveness of discussions and conclusions, and the generalization or transferability of the study's findings. Articles that scored less than $80 \%$ ( 14 of 17 items or less) were excluded.

Methodological weaknesses included poor use of theory, not addressing a comprehensive and up-to-date literature review (qualitative and quantitative), not stating the philosophical background and the rationale for the choice of design not being evident, and not identifying the major concepts (qualitative). Nonetheless, these studies provided useful and credible findings, which are relevant to the topic of this IR.

\section{Data Analysis}

Articles were recorded on data coding sheets that consisted of the following subheadings: author, country, research design, setting, aim of the study, sample, data collection, and key findings regarding the factors associated with the attitudes and experiences of women with SMD. The results from quantitative, qualitative and mixed-method studies were described, compared item by item, and explored for similarities, differences and relationships between data (Whittemore \& Knafl, 2005).

A narrative synthesis approach was used to synthesize both qualitative and quantitative evidence. This process involved the conversion of all data into narrative through qualitative analysis (Mays, Pope, \& Popay, 2005). The quantitative findings were translated into narrative 
Table 1

Data Extraction

\begin{tabular}{|c|c|c|c|c|}
\hline $\begin{array}{l}\text { Author, country, } \\
\text { research design, } \\
\text { setting }\end{array}$ & Aim of the study & Sample & Data collection & Key findings \\
\hline \multicolumn{5}{|l|}{ Quantitative studies } \\
\hline $\begin{array}{l}\text { Sajatovic et al. } \\
\text { (2006) } \\
\text { United States of } \\
\text { America (USA) } \\
\text { Cross sectional } \\
\text { Impatient and } \\
\text { outpatient clinic } \\
\text { and community } \\
\text { mental health } \\
\text { clinic }\end{array}$ & $\begin{array}{l}\text { To examine expectations and concerns } \\
\text { regarding menopause among women } \\
\text { with severe mental illness (SMI) }\end{array}$ & $\begin{array}{l}91 \text { women from } 45 \text { to } 55 \text { years of age } \\
\text { diagnosed with schizophrenia/ } \\
\text { schizoaffective disorder, bipolar } \\
\text { disorder, or major depression for a } \\
\text { minimum of } 2 \text { years with onset of } \\
\text { perimenopause and menopause }\end{array}$ & $\begin{array}{l}\text { - 13-item questionnaire to } \\
\text { explore fund of knowledge; } \\
\text { 9-item questionnaire to } \\
\text { evaluate subjective } \\
\text { experiences regarding } \\
\text { menopause } \\
\text { - Menopause-Specific Quality } \\
\text { of Life Questionnaire } \\
\text { (MENQOL) } \\
\text { - Clinical global impressions } \\
\text { to measure illness severity } \\
\text { - Global Assessment Scale } \\
\text { (GAS) to measure overall } \\
\text { global functioning }\end{array}$ & $\begin{array}{l}\text { - } 71 \% \text { were not employed outside } \\
\text { home } \\
\text { - } 56 \% \text { had a history of physical or } \\
\text { sexual abuse } \\
\text { - } 26 \% \text { had a history of substance abuse } \\
\text { - Statistical association between lower } \\
\text { fund of knowledge scores and: } \\
\text { - Lower educational levels } \\
\text { ( } R \mathrm{p}=0.44, p=0.0001 \text { ) } \\
\text { - Minority ethnic status ( } R \text { s }=.23 \text {, } \\
p=0.03 \text { ) } \\
- \text { The stronger predictor for fund of } \\
\text { knowledge regarding menopause was } \\
\text { the education ( } p=0.0003 \text { ) } \\
-75 \% \text { reported physical symptoms } \\
\text { related to menopause } \\
\text { - } 87 \% \text { experienced symptoms of } \\
\text { feeling tired or worn out } \\
\text { - } 86 \% \text { reported lack of energy } \\
\text { - } 84 \% \text { complained about poor memory } \\
\text { and aches in muscles or joints } \\
\text { - } 60 \% \text { reported emotional symptoms } \\
\text { related to menopause and that } \\
\text { menopause was affecting emotional } \\
\text { status } \\
\text { - } 88 \% \text { reported depression and anxiety } \\
\text { as most common symptoms related to } \\
\text { menopause } \\
-51.6 \% \text { suffered negative effects in the } \\
\text { scope of emotional status }\end{array}$ \\
\hline \multicolumn{5}{|l|}{ Qualitative studies } \\
\hline $\begin{array}{l}\text { Birch et al., } 2005 \\
\text { United Kingdom } \\
\text { (UK) } \\
\text { Interpretative } \\
\text { Phenomenological } \\
\text { Analysis (IPA) } \\
\text { Community men- } \\
\text { tal health services }\end{array}$ & $\begin{array}{l}\text { To explore women's experiences of } \\
\text { healthcare, the way in which their } \\
\text { physical health needs had been } \\
\text { addressed and how these experiences } \\
\text { had affected them }\end{array}$ & $\begin{array}{l}\text { Six women from } 19 \text { to } 53 \text { years-old, } \\
\text { with medical diagnosis of bipolar } \\
\text { disorder or schizophrenia }\end{array}$ & - Semi-structured interviews & $\begin{array}{l}\text { Themes and subthemes: } \\
\text { 1 Experiences of physical healthcare } \\
\text { that afforded status: } \\
\text { - Feelings of being in control } \\
\text { - Desirable outcome } \\
\text { - Emotional nurture } \\
\text { 2 Experiences of physical healthcare } \\
\text { which were stigmatizing: } \\
\text { - Powerlessness } \\
\text { - Objectification } \\
\text { - Lack of knowledge } \\
\text { - Feelings of inadequacy and guilt }\end{array}$ \\
\hline $\begin{array}{l}\text { Borba et al., } 2011 \\
\text { USA } \\
\text { Qualitative public } \\
\text { hospital }\end{array}$ & $\begin{array}{l}\text { To describe and interpret women's } \\
\text { experiences and provide a new } \\
\text { understanding about the nature and } \\
\text { needs of these women }\end{array}$ & $\begin{array}{l}30 \text { low-income urban women from } \\
28 \text { to } 62 \text { years-old with diagnosis of } \\
\text { SMI }\end{array}$ & $\begin{array}{l}\text { - Face-to-face, in-depth } \\
\text { interviews }\end{array}$ & $\begin{array}{l}\text { Themes: } \\
\text { - Social isolation } \\
\text { - Fear of hospitalization } \\
\text { - Moving to different } \\
\text { neighborhoods } \\
\text { - Experiencing losses-job, } \\
\text { relationship, children } \\
\text { - Lack of control over one's own life } \\
\text { decisions }\end{array}$ \\
\hline $\begin{array}{l}\text { Chernomas et al., } \\
2000 \\
\text { Canada } \\
\text { Qualitative } \\
\text { Community }\end{array}$ & $\begin{array}{l}\text { To investigate the perceptions of } \\
\text { women with schizophrenia or } \\
\text { schizoaffective disorder about their } \\
\text { illness in the context of their life stages } \\
\text { and corresponding health needs }\end{array}$ & $\begin{array}{l}28 \text { women with schizophrenia or } \\
\text { schizoaffective disorder }\end{array}$ & Focus groups & $\begin{array}{l}\text { - Work } \\
\text { - Stigma and rejection } \\
\text { - Relationships and intimacy } \\
\text { - Pregnancy and motherhood } \\
\text { - Responsibility for illness } \\
\text { - Physical health and interaction } \\
\text { with a physician } \\
\text { - Hope and spirituality }\end{array}$ \\
\hline $\begin{array}{l}\text { Diaz-Caneja \& } \\
\text { Johnson, } 2004 \\
\text { UK } \\
\text { Qualitative } \\
\text { Community } \\
\text { mental health } \\
\text { services }\end{array}$ & $\begin{array}{l}\text { To explore the experiences of severely } \\
\text { mentally ill mothers and their views of } \\
\text { the services they received }\end{array}$ & $\begin{array}{l}22 \text { women on the caseloads of } \\
\text { community mental health teams }\end{array}$ & Semi-structured interviews & $\begin{array}{l}\text { Themes: } \\
\text { - Positive aspects of motherhood } \\
\text { - Difficulties associated with } \\
\text { motherhood } \\
\text { - Effect of mental illness on children } \\
\text { - Stigma } \\
\text { Views about services: } \\
\text { - Custody loss } \\
\text { - Adult mental health services } \\
\text { - Other agencies } \\
\text { - Arrangements when mothers were }\end{array}$ \\
\hline
\end{tabular}


Table 1 (continued)

\begin{tabular}{|c|c|c|c|c|}
\hline $\begin{array}{l}\text { Author, country, } \\
\text { research design, } \\
\text { setting }\end{array}$ & Aim of the study & Sample & Data collection & Key findings \\
\hline & & & & $\begin{array}{l}\text { unable to look after their children } \\
\text { - Service needs }\end{array}$ \\
\hline $\begin{array}{l}\text { Lyon \& Parker, } 2003 \\
\text { USA } \\
\text { Qualitative } \\
\text { Psychosocial } \\
\text { clubhouses }\end{array}$ & $\begin{array}{l}\text { To investigate the perceptions of rural } \\
\text { women with severe and persistent } \\
\text { mental illness (SPMI) about their } \\
\text { gender-related health concerns }\end{array}$ & $\begin{array}{l}16 \text { women from } 27 \text { to } 64 \text { years of age, } \\
\text { with diagnoses of chronic } \\
\text { schizophrenia, paranoid } \\
\text { schizophrenia, psychotic disorder, } \\
\text { major depression, and hebephrenia }\end{array}$ & Focus groups & $\begin{array}{l}\text { Themes: } \\
1 \text { Body-image changes/menstrual } \\
\text { disruptions } \\
2 \text { Difficulty in obtaining regular health } \\
\text { services and communicating with } \\
\text { health care professionals } \\
3 \text { Risk of interpersonal violence } \\
4 \text { Prenatal loss and/or loss of children }\end{array}$ \\
\hline $\begin{array}{l}\text { Manuel et al., } 2012 \\
\text { USA } \\
\text { Qualitative } \\
\text { Transitional } \\
\text { residences on the } \\
\text { grounds of two } \\
\text { psychiatric } \\
\text { hospitals }\end{array}$ & $\begin{array}{l}\text { To explore the experience of women } \\
\text { with SMI in transition from psychiatric } \\
\text { hospital care to the community }\end{array}$ & $\begin{array}{l}25 \text { women from } 18 \text { to } 59 \text { years-old } \\
\text { diagnosed with SMI; previously } \\
\text { homeless and awaiting community } \\
\text { placement; hospitalized for at least } \\
1 \text { month before discharge }\end{array}$ & Focus groups & $\begin{array}{l}\text { Themes: } \\
\text { 1 Barriers to transition and community } \\
\text { integration } \\
\text { - Fear or insufficient treatment } \\
\text { support } \\
\text { - Social isolation } \\
\text { - Safety concerns } \\
\text { - Stigma } \\
\text { - Lack of resources to meet daily } \\
\text { needs } \\
2 \text { Facilitators of transition and } \\
\text { community integration } \\
\text { - Orientation to neighborhood and } \\
\text { residence } \\
\text { - Access to treatment support with } \\
\text { flexibility } \\
\text { - Connection to social supports }\end{array}$ \\
\hline $\begin{array}{l}\text { Montgomery et al., } \\
2006 \\
\text { Canada } \\
\text { Grounded theory } \\
\text { Inpatient unit } \\
\text { within general } \\
\text { hospital; outpa- } \\
\text { tient and acute } \\
\text { care mental } \\
\text { health services }\end{array}$ & $\begin{array}{l}\text { To describe the experiences of mothers } \\
\text { with SMI from the point of view of } \\
\text { participants and how they manage } \\
\text { these problems }\end{array}$ & $\begin{array}{l}21 \text { women from } 20 \text { to } 30 \text { years-old } \\
\text { under a psychiatrist's care for a major } \\
\text { mental illness for more than } 2 \text { years; } \\
\text { mothers of at least one child, aged } \\
\text { from } 2 \text { to } 15 \text { years-old }\end{array}$ & $\begin{array}{l}\text { Individual interviews and } \\
\text { field notes }\end{array}$ & $\begin{array}{l}\text { Core category } \\
\text { Keeping close } \\
\text { - Appearing normal } \\
\text { - Creating security } \\
\text { - Being responsible } \\
\text { - Subcategories of keeping close } \\
\text { - Masking } \\
\text { - Censoring speech } \\
\text { - Doing mother work } \\
\text { - Seeking help }\end{array}$ \\
\hline $\begin{array}{l}\text { Nicolaidis et al., } \\
2010 \\
\text { USA } \\
\text { Community- } \\
\text { based participator } \\
\text { research } \\
\text { Community }\end{array}$ & $\begin{array}{l}\text { To understand how African American } \\
\text { women's beliefs regarding depression } \\
\text { and depression care are influenced by } \\
\text { racism, violence, and social context }\end{array}$ & $\begin{array}{l}30 \text { low-income African American } \\
\text { women with major depressive disor- } \\
\text { der and histories of violence } \\
\text { victimization }\end{array}$ & $\begin{array}{l}\text { - Depression Scale of the } \\
\text { Patient Health Questionnaire } \\
\text { - Questionnaire to identify } \\
\text { occurrence of intimate } \\
\text { partner violence } \\
\text { - Focus groups }\end{array}$ & $\begin{array}{l}\text { Themes: } \\
1 \text { Individual experiences } \\
\text { - Violence, drug use, and depression } \\
\text { are hard to separate } \\
\text { - Abuse "messes you up" } \\
\text { - Violence victimization leads to } \\
\text { perpetration } \\
2 \text { Health care system } \\
\text { - Intergenerational messages to } \\
\text { avoid health care } \\
\text { - Mistrust of the health care system } \\
\text { as a "White" system. } \\
\text { - Negative experiences with health } \\
\text { care attributed to racism } \\
3 \text { Depression and depression care } \\
\text { - Expectation to be a "strong Black } \\
\text { woman" acts as a barrier. } \\
\text { - Negative attitudes toward } \\
\text { antidepressants } \\
\text { - Preference for self-care and } \\
\text { counseling } \\
4 \text { Preferences for a depression care } \\
\text { intervention } \\
\text { - Program staffed by and targeted } \\
\text { toward African Americans. } \\
\text { - Personal experience valued over } \\
\text { professional credentials } \\
\text { - Creative arts-based program that } \\
\text { addresses practical life issues. }\end{array}$ \\
\hline $\begin{array}{l}\text { Pickens, } 2003 \\
\text { USA } \\
\text { Case study } \\
\text { primary } \\
\text { psychiatric care } \\
\text { clinic }\end{array}$ & $\begin{array}{l}\text { To describe formal and informal social } \\
\text { networks of four women with serious } \\
\text { mental illness and to capture what } \\
\text { happens in network interactions }\end{array}$ & $\begin{array}{l}\text { - Four women from } 18 \text { to } 65 \text { years of } \\
\text { age with diagnosis of bipolar disorder } \\
\text { or schizoaffective disorder }\end{array}$ & $\begin{array}{l}\text { - In-depth, semi structured } \\
\text { interviews } \\
\text { - Observation } \\
\text { - Participant-observation } \\
\text { - Document review }\end{array}$ & $\begin{array}{l}\text { Network structure } \\
\text { - Informal composition: family, } \\
\text { friends, church, coresidents of a } \\
\text { supervisory care home, neighbors, } \\
\text { acquaintances, adult centers } \\
\text { - Formal composition: professionals } \\
\text { at a psychiatric clinic and patients, } \\
\text { community organizations, }\end{array}$ \\
\hline
\end{tabular}


Table 1 (continued)

\begin{tabular}{|c|c|c|c|c|}
\hline $\begin{array}{l}\text { Author, country, } \\
\text { research design, } \\
\text { setting }\end{array}$ & Aim of the study & Sample & Data collection & Key findings \\
\hline $\begin{array}{l}\text { Skärsäter et al., } \\
2003 \\
\text { Sweden } \\
\text { Phenomenology } \\
\text { Impatient care in } \\
\text { psychiatric } \\
\text { departments }\end{array}$ & $\begin{array}{l}\text { To describe women's conceptions of } \\
\text { coping with major depression in daily } \\
\text { life with the help of professional and } \\
\text { lay support. }\end{array}$ & $\begin{array}{l}13 \text { Swedish-speaking women, } \\
\text { previously hospitalized for major } \\
\text { depression (during the period } \\
\text { 1997-1998) }\end{array}$ & $\begin{array}{l}\text { - In-depth interviews, } \\
\text { professionals to support you } \\
\text { to stay well? }\end{array}$ & $\begin{array}{l}\text { governmental and community } \\
\text { agencies hospitals, human resources, } \\
\text { crisis teams, and the police. } \\
\text { Network function } \\
\text { - Supportive roles: social, emotional, } \\
\text { concrete/material, and guidance roles } \\
\text { - Reciprocity } \\
\text { - Conflict } \\
\text { - Stability } \\
\text { Descriptive categories: } \\
\text { 1 Self- healing } \\
\text { - Gaining space for oneself - need of } \\
\text { time for reflections } \\
\text { - Being confirmed - feeling of security } \\
\text { when the diagnosis is received } \\
\text { - Being seen - need to be seen as an } \\
\text { individual, to be taken seriously and to } \\
\text { have value } \\
2 \text { Managing } \\
\text { - Having personal strategies-dealing } \\
\text { with depressive symptoms } \\
\text { - Undergoing a process of } \\
\text { transition-view of themselves and } \\
\text { other people altered } \\
\text { - Becoming empowered through an } \\
\text { inner strength } \\
\text { 3 Receiving social support } \\
\text { - Regaining command over the } \\
\text { everyday structure - helped by the } \\
\text { people around } \\
\text { - Being part of a fellowship-helped to } \\
\text { restore health being together with } \\
\text { others. } \\
\text { - Receiving information-helped by } \\
\text { the information received } \\
4 \text { Finding a meaning } \\
\text { - Reflecting over one's life: the period } \\
\text { of illness had given to women the } \\
\text { possibility to reflect } \\
\text { - Believing in the future: the women } \\
\text { developed a sense of confidence in the } \\
\text { future as well as plans }\end{array}$ \\
\hline $\begin{array}{l}\text { Sosulski, } 2010 \\
\text { USA } \\
\text { Life history and } \\
\text { feminist narrative } \\
\text { analysis } \\
\text { Community }\end{array}$ & $\begin{array}{l}\text { To explore women's everyday } \\
\text { experiences with mental illness, from } \\
\text { their perspectives }\end{array}$ & $\begin{array}{l}\text { A Black women living with severe } \\
\text { mental illness (SMI) }\end{array}$ & $\begin{array}{l}\text { In-depth, face to face } \\
\text { interviews }\end{array}$ & $\begin{array}{l}\text { - Mental illness as an aspect of life that } \\
\text { triggered violence and sexually risk } \\
\text { behaviors } \\
\text { - A better understanding of mental } \\
\text { health issues led to significant growth } \\
\text { of personal and political awareness } \\
\text { - SMI affected the abilities to work and } \\
\text { participate in social life } \\
\text { - African American women with SMI } \\
\text { struggled with issues related to family, } \\
\text { work, community, and gender and ra- } \\
\text { cial discrimination } \\
\text { - Family members, community, and } \\
\text { professionals were recognized as sup- } \\
\text { portive resources }\end{array}$ \\
\hline $\begin{array}{l}\text { Mixed-method studie } \\
\text { Benders-Hadi et al., } \\
2013 \\
\text { USA } \\
\text { A large state } \\
\text { psychiatric } \\
\text { hospital }\end{array}$ & $\begin{array}{l}\text { - To determine the prevalence of } \\
\text { motherhood among inpatient females } \\
\text { at psychiatric hospital } \\
\text { - To develop an understanding of the } \\
\text { characteristics and needs of this unique } \\
\text { population. }\end{array}$ & 24 impatient mothers with SMI & $\begin{array}{l}\text { - Survey } \\
\text { - Focus groups }\end{array}$ & $\begin{array}{l}\text { - } 45.8 \% \text {-weekly contact with children } \\
\text { - } 54.2 \% \text {-no history of any child } \\
\text { welfare involvement } \\
\text { - } 50 \% \text { - primary caretakers of their } \\
\text { children growing up } \\
\text { - Mother's role is considered } \\
\text { important to give purpose to life } \\
\text { - Stigma: people with mental illness } \\
\text { are supposed to be inevitably bad } \\
\text { parents } \\
\text { - } 79.2 \% \text { mentioned motherhood in } \\
\text { their treatment plans } \\
\text { - Half of this subgroup-simply } \\
\text { noted but not elaborated upon }\end{array}$ \\
\hline
\end{tabular}


Table 1 (continued)

\begin{tabular}{|c|c|c|c|c|}
\hline $\begin{array}{l}\text { Author, country, } \\
\text { research design, } \\
\text { setting }\end{array}$ & Aim of the study & Sample & Data collection & Key findings \\
\hline
\end{tabular}

Dipple et al., 2002

UK

Case-note study, mixed method

Psychiatric

services
To address the experience of motherhood of women with severe mental disorders who are patients of the psychiatric rehabilitation services
- 58 long-term female psychiatric service users who were mothers

To examine the impact of serious mental illness (SMI) on female sexual functioning; to determine personal and contextual barriers in sexual health of women with Axis-I disorders.

Matevosyan, 2010
USA
Exploratory,
mixed-method
studies
Psychiatric
rehabilitation
program

44 women with SMI

- Two questionnaires to assess perceived sexual functioning: Brief Index of Sexual Functioning for Women (BISF-W) - Sexual Function Questionnaire for Clinical Trials of Female Sexual Dysfunction

- Behavior and Symptom Identification Scale (BASIS24).

- Semi-structured interviews
- The other half of treatment plans had mention of this role that was expanded upon; included reference to clinicians and patients having contact with children

- $68 \%$ - had at least one child who were permanently separated from before the child was 18 years-old

- Multi-factorial reasons for separation:

- Inadequate care appraised by authorities (41\%)

- Prolonged hospitalization of the mother ( $52 \%$ of children), and a breakdown in the mother's relationship with the father ( $54 \%$ of children)

- $47 \%$ of women permanently separated from their children expressed delusions or overvalued ideas involving their children during the course of their illness - Some women expressed a great sadness, anger or frustration related to separations many years before - Multiple losses: health, role as mothers, meaningful relationships with children, relationships with partners, parental rights and personal freedom due to hospitalization

- Infrequent use of condom

- 68.2\% approved condoms

- 34\% reported STI

- 16\% reported STI in their partners - Suboptimal sexual health - 59\%-history of sexual abuse (59\%) - 72.7\%-long-term sex abstinence

- 86.3\%-client-provider poor communications

- 79.6\%-lack of awareness towards sexual health

- Sexual satisfaction and pleasure - Affected by higher scores of psychotropic medications (4.8 \pm 6.3 ), length of psychotropic treatment $(10.8 \pm 9.1)$, impaired interpersonal skills, and emotional lability health

- Major barriers for sexual health

- Health insurance limitations

- Lack of awareness in sexual health needs

- Stigma

- Poor provider-client communication statements, and then closely apposed to the qualitative evidence in order to enable a deeper understanding of, and a critical reflection upon the quantitative findings (Barnett, Guell, \& Ogilvie, 2012; Pearson et al., 2014). Similar findings were then categorized and grouped through an iterative process of reading and re-reading of the studies retrieved. Themes related to the factors associated with experiences and daily life attitudes of adult women experiencing SMD were identified (Barnett et al., 2012; Whittemore \& Knafl, 2005).

\section{RESULTS}

Among the 15 studies included in this IR, the major proportion ( $n=$ 11) was performed using qualitative methods, three used mixed methods, and one used a quantitative method. These studies were from the following four countries: USA ( $n=9)$, UK $(n=3)$, Canada $(n=2)$, and Sweden $(n=1)$. The study settings were psychiatric outpatient/impatient units in the hospital, primary health care, community mental health services, transitional residences, and the community. All of the studies approached the women's experiences and daily life attitudes towards SMD using several perspectives, due to the heterogeneous findings.

We could identify 21 factors associated with the experiences and attitudes in women with SMD. These factors were pooled into the following five categories (Fig. 2): 1) strengths and limitations regarding selfcare behavior and healthcare delivery; 2) unmet healthcare needs; 3) psychosocial vulnerabilities underlying SMD; 4) gains and challenges of motherhood; and 5) adoption of coping strategies.

The recommendations for practices and further studies are reported in Table 2. 


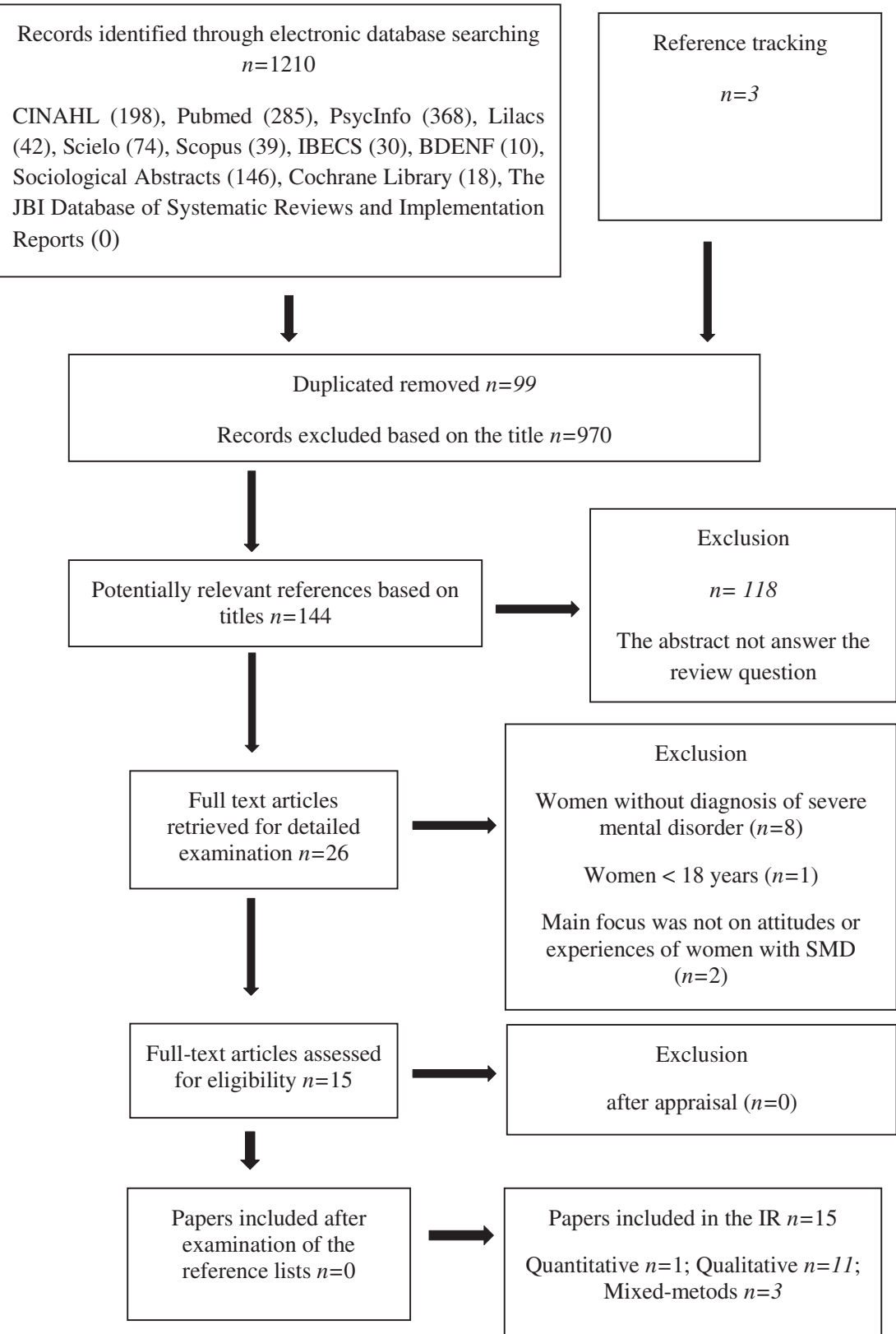

Fig. 1. Search process.

Strengths and Limitations Regarding Self-Care Behavior and Healthcare Delivery

Positive Relationships With Professionals

Four studies focused on the women's experiences towards healthcare and the support received by them (Birch et al., 2005; DiazCaneja \& Johnson, 2004; Manuel, Hinterland, Conover, \& Herman, 2012; Skärsäter, Dencker, Bergbom, Häggström, \& Fridlund, 2003). In general, the women were satisfied with their healthcare. Desired characteristics in their healthcare providers were availability, supportive behavior, sympathetic and skillful care. Continuous support was seen as a great strategy that is essential to help them to find both structure and hope in acute situations (Diaz-Caneja \& Johnson, 2004; Manuel et al., 2012; Skärsäter et al., 2003). Their experiences of their physical healthcare were also seen to be positive due to their feelings of having control over treatments as well as the possibility of coping with their ill conditions (Birch et al., 2005).
Poor Relationships With Professionals and Barriers to Access Care

Six studies explored women's perceptions regarding their interactions with healthcare providers and their access to healthcare (Birch et al., 2005; Chernomas, Clarke, \& Chisholm, 2000; Diaz-Caneja \& Johnson, 2004; Lyon \& Parker, 2003; Matevosyan, 2010; Nicolaidis et al., 2010). Difficulties in obtaining regular health services and in communicating properly with healthcare providers who were not specialists in psychiatry were reported (Chernomas et al., 2000; Lyon \& Parker, 2003; Matevosyan, 2010).

Limitations regarding health insurance, lack of adequate information about what their health plan covers, access to gynecologic exams (Pap smear and mammograms), and access to primary healthcare were the main barriers confronted by women. Women felt invisible in the healthcare system due to poor communication with care providers, who were focused on the disease. This complaint particularly reflects the lack of opportunities they had to discuss their needs and concerns regarding women's health issues, such as menstrual irregularities and 
Factors related to attitudes and experiences

Positive relationships with professionals

Poor relationships with professionals and barriers to access

healthcare

Poor information on women's health issues

The burden of physical and psychological symptoms

Adequate support for manage the treatment

Help to integrate patients into community

Health information

Approach of the complex social situations

Approach of daily life experiences

Group interventions to patients and their family

Listening without judgements

Stigma and discrimination

Social isolation

Barriers to employment

Interpersonal violence and sexually risk behaviors
Categories
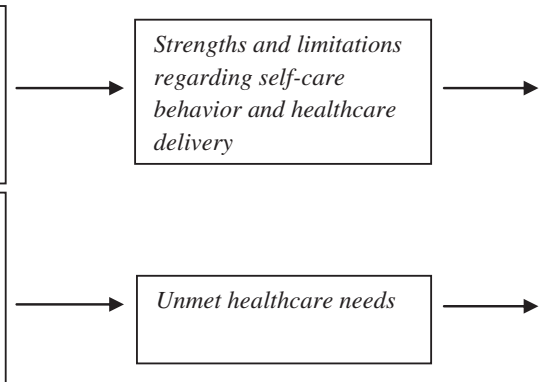

Women need a sensitive and comprehensive healthcare support, which take in account their subjective perspectives, and integrate mental health issues into their psychosocial context
Constructive behaviors toward health

Dealing with difficulties

Beliefs and attitudes influenced by culturally shaped

gender roles

Dissatisfaction with healthcare

\section{Social support}

Personal strategies

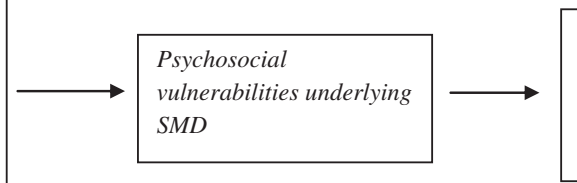

Women with SMD constitute a vulnerable group, which have been suffered with stigmatization and discrimination, and face social and personal barriers to participate in social life and make informed choices about health

Motherhood comprises gains and challenges, an women adopt strategies embodied by gendered ideals of mothering to deal with difficulties exacerbated by their mental health conditions

Women develop strategies to cope with adversity through seeking for the improvement of interpersonal relationships and social connection, as well as they adopt personal strategies to strength their spirituality and deal with everyday life situations.

Fig. 2. Summary of factors associated with experiences and daily life attitudes of women with SMD.

sex (Birch et al., 2005; Chernomas et al., 2000; Lyon \& Parker, 2003; Matevosyan, 2010).

Gender roles, responsibilities regarding motherhood (Diaz-Caneja \& Johnson, 2004), and intergenerational messages that suggest avoiding healthcare and the need to handle their own health issues (Nicolaidis et al., 2010) were reported to be barriers to seeking care. The AfricanAmerican women attributed their attitudes of avoiding healthcare to the racism they have suffered in the healthcare system as a consequence of the racially biased care system (Nicolaidis et al., 2010).

\section{Poor Information on Women's Health Issues}

The lack of information regarding women's health issues was identified in five studies (Birch et al., 2005; Chernomas et al., 2000; Lyon \& Parker, 2003; Matevosyan, 2010; Sajatovic et al., 2006). Family planning, pregnancy, parenting, sexual health, menopause, preventive gynecologic care, nutrition, and the side effects of psychopharmacologic treatment could have been addressed by better health information (Chernomas et al., 2000; Lyon \& Parker, 2003; Matevosyan, 2010). The poor knowledge of SMD was seen as a barrier to take informed choices about treatment and self-care practices. This situation contributed to the feelings of apprehension, insecurity, frightening, and powerlessness (Birch et al., 2005; Lyon \& Parker, 2003).

\section{The Burden of Physical and Psychological Symptoms}

The physical and psychological problems confronted by women were reported in five studies (Birch et al., 2005; Chernomas et al., 2000; Lyon \& Parker, 2003; Matevosyan, 2010; Sajatovic et al., 2006). The side effects of antipsychotic medications, such as weight gain, amenorrhea, decreased libido, fatigue, lactation, and facial hair, adversely affected the women's sense of self and femininity, contributing to the exacerbation of the aging process. Such symptoms provoked negative impacts on social life and productivity (Birch et al., 2005; Chernomas et al., 2000; Lyon \& Parker, 2003; Matevosyan, 2010; Sajatovic et al., 2006).
Sexual satisfaction was the part of women's life that was most affected by the symptoms of SMD. This problem has been associated with the use of psychotropic medications and length of treatment (Matevosyan, 2010). The side effects of these medications also impaired the women's ability to fulfill their children's needs. The women felt that medications slowed them down and reduced the concentration they need for their roles as mothers (Diaz-Caneja \& Johnson, 2004).

Negative experiences regarding menopause, particularly its physical and psychological symptoms, have affected the women's well-being. Exacerbations in psychological symptoms, such as depression and anxiety, can aggravate their quality of life and mental health outcomes (Sajatovic et al., 2006).

\section{Unmet Healthcare Needs}

Unmet care needs were reported in six studies (Borba et al., 2011; DiazCaneja \& Johnson, 2004; Manuel et al., 2012; Montgomery, Tompkins, Forchuk, \& French, 2006; Nicolaidis et al., 2010; Skärsäter et al., 2003). The women's main perceived needs were adequate support in managing treatments, help integrating into the community, information about women's health issues (also provided to family members, friends, and others who can support them), approaches for complex social situations, group interventions for patients and their families, and listening without judgment (Diaz-Caneja \& Johnson, 2004; Manuel et al., 2012; Nicolaidis et al., 2010; Skärsäter et al., 2003).

Women also need resources to approach their daily life experiences and issues such as domestic violence, substance abuse, housing, employment, education, parental roles, transportation, and child care (Borba et al., 2011; Diaz-Caneja \& Johnson, 2004; Nicolaidis et al., 2010; Skärsäter et al., 2003). Studies also reported that women wanted healthcare provided in the community and the use of all available resources to help them to obtain jobs, housing, and education (Borba et al., 2011; Manuel et al., 2012; Skärsäter et al., 2003). Women want 
Table 2

Recommendations Given by the Authors of Empirical Studies for Practice and Further Studies.

Recommendations for practice

Women's supportive care needs

- Be sensitive to SMD's motherhood roles, taking into account the sociocultural backgrounds as well as their personal and social needs. (Benders-Hadi et al., 2013; Dipple et al., 2002; Montgomery et al., 2006)

- Offer support groups for mentally ill mothers (Diaz-Caneja \& Johnson, 2004)

- Provide safe, practical, and emotional support in parenting through listening without judgments and addressing subjective matters (Benders-Hadi et al., 2013; Diaz-Caneja \& Johnson, 2004; Dipple et al., 2002; Montgomery et al., 2006)

- Advocate for women in obtaining legal help to maintain contact with children (Dipple et al., 2002)

- Create healthy possibilities for severe mental ill mothers nurturing their children (Montgomery et al., 2006)

- Take a sexual history as integral part of psychiatric assessment (Matevosyan, 2010)

- Provide appropriate information about menopausal symptoms, in order to improve physical and mental health outcomes (Sajatovic et al., 2006)

- Recognize women's strengths, skills, and limitations and help them to develop coping strategies to deal with difficult situations and overcome daily problems (Pickens, 2003; Skärsäter et al., 2003; Sosulski, 2010)

- Provide fully consent healthcare through participatory practices (Birch et al., 2005; Borba et al., 2011)

- Promote women's empowerment (Birch et al., 2005; Skärsäter et al., 2003)

- Understand that individuals may have different styles for being in contact with others, and be sensitive to the diverse degree of importance attributed by the women to their relationships (Dipple et al., 2002; Pickens, 2003)

- Develop and evaluate strategies for assessing and meeting the complex women's health needs through development of health education and promotion activities (Diaz-Caneja \& Johnson, 2004; Lyon \& Parker, 2003)

- Address needs related to complex social situations and help women to improve practical skills to deal with social isolation, stigma, discrimination, racism, violence, poverty, and substance abuse (Birch et al., 2005; Borba et al., 2011; Nicolaidis et al., 2010; Pickens, 2003)

Mental health care in the community

- Engage women in discussions of their options for community living and treatment available (Borba et al., 2011; Manuel et al., 2012

- Provide support to bolster the women's capacity for independent actions, and promote community integration helping them to obtain jobs, housing, education, and appropriate treatment (Borba et al., 2011; Manuel et al., 2012)

- Assist the women in identifying social network resources, and evaluate the potential contributions and needs of these resources (Pickens, 2003; Skärsäter et al., 2003)

Continuing education for health care providers

- Implement training and guidance to health care providers focused on assessment and support of mentally ill mothers (Diaz-Caneja \& Johnson, 2004)

- Prepare a multidisciplinary team to provide support for women with SMD (Borba et al., 2011; Chernomas et al., 2000)

Recommendations for further empirical studies

- Investigate the intersection between having SMD and living with a history of violence and substance abuse (Borba et al., 2011)

- Explore the negative experiences of symptoms and to investigate the areas of suicide and substance abuse (Chernomas et al., 2000)

- Explore the experiences of motherhood lived by women with SMD and their children (Diaz-Caneja \& Johnson, 2004)

- Explore factors of treatment that women find helpful or less helpful to develop a broader understanding of stigma and its impact on community integration (Manuel et al., 2012)

- Investigate the perceived sexual function among women with SMD considering the psychiatric assessment (Matevosyan, 2010)

- Investigate the effectiveness of culturally specific interventions in reducing depression severity and improving depression care among African American women (Nicolaidis et al., 2010)

- Investigate informal network members/explore the issue of reciprocity in relationships between individuals with SMD and their network members/ explore social networks of people with mental illness over time/explore the possible association between conflicts in relationships and coping styles (Pickens, 2003)

- Explore the circumstances that empower women to start the transition process for recovery from major depression/evaluate intervention programs of patient education regarding how to cope with major depression (Skärsäter et al., 2003)

- Explore the experiences of Black women with SMD recognizing the context in which they live (Nicolaidis et al., 2010) to increase their independence and self-determination as well as to be treated as valued people (Manuel et al., 2012; Montgomery et al., 2006; Skärsäter et al., 2003).

\section{Psychosocial Vulnerabilities Underlying SMD}

\section{Stigma and Discrimination}

The stigma associated with SMD was reported in six studies (Birch et al., 2005; Chernomas et al., 2000; Diaz-Caneja \& Johnson, 2004; Manuel et al., 2012; Matevosyan, 2010; Nicolaidis et al., 2010). The restrictive social messages related to the women's social inabilities from their diagnosis have led women to feel judged, inadequate, guilty, and powerless to control their own lives (Birch et al., 2005; Chernomas et al., 2000).

The physical healthcare received by women, particularly regarding their sexual and reproductive health, was experienced as negative and stigmatizing by women with SMD (Birch et al., 2005; Chernomas et al., 2000).

\section{Social Isolation}

Women with SMD reported social isolation in five studies (Borba et al., 2011; Chernomas et al., 2000; Dipple, Smith, Harry, \& Evans, 2002; Manuel et al., 2012; Sosulski, 2010). An overwhelming sense of loneliness and isolation was associated with restricted social support, difficulties in making or preserving friends, and a sense of disproportional affection in their abilities to work and participating in social life (Borba et al., 2011; Manuel et al., 2012; Sosulski, 2010).

Multiple losses as an effect of SMD were reported. The main losses were related to the women's difficulties in playing their roles as mothers, the poor quality of their relations with children and partners, their parental rights, and personal freedom due to hospitalizations (Borba et al., 2011; Chernomas et al., 2000; Dipple et al., 2002).

\section{Barriers to Employment}

Social and personal barriers to employment were reported in four studies (Borba et al., 2011; Chernomas et al., 2000; Manuel et al., 2012; Sajatovic et al., 2006). Some women experienced ambivalent feelings regarding employment (Borba et al., 2011; Chernomas et al., 2000; Manuel et al., 2012). Even though they wanted to get a job, women were afraid of being unable to handle the stress of working. Consequently, they declined to pursue one even considering their poor financial resources. Furthermore, they were afraid of losing their welfare or pension benefits if they got a job and chose to be homemakers or stay on disability pensions to pay for their basic needs.

\section{Interpersonal Violence and Risky Sexual Behaviors}

The risks of interpersonal violence in the scope of sexual behaviors were reported in six studies (Borba et al., 2011; Chernomas et al., 2000; Matevosyan, 2010; Nicolaidis et al., 2010; Sosulski, 2010). Concerns about perpetuating violence against their partners, children, or others were reported (Chernomas et al., 2000; Nicolaidis et al., 2010; Sosulski, 2010). The women's perceptions of emotional and physical vulnerability and victimization as well as the large, long-lasting impact of violence on their lives, self-images, choices, and behaviors were described by two studies (Chernomas et al., 2000; Nicolaidis et al., 2010). Women also faced challenges related to their connections with others in intimate relations, as the strain of relationships was viewed as a reason for their relapse (Chernomas et al., 2000).

Mental disorder was seen as an aspect of life that can be troubling and may trigger risky sexual behaviors (Sosulski, 2010). The lack of inadequate medication may trigger feelings of guilt, and regret surrounded their stories of early promiscuity and prostitution. A large occurrence of unplanned pregnancies was reported by women as well (Chernomas et al., 2000). 


\section{Gains and Challenges of Motherhood}

\section{Constructive Behaviors Toward Health}

The positive aspects of motherhood were reported in four studies (Benders-Hadi, Barber, \& Alexander, 2013; Chernomas et al., 2000; Diaz-Caneja \& Johnson, 2004; Montgomery et al., 2006). The mothers' role was seen as rewarding and central to the women's lives. Motherhood was seen as a way to have a purpose in life, to feel fulfilled and have an increased self-esteem. Motherhood also increased their sense of confidence, love, and identity (Chernomas et al., 2000; Diaz-Caneja \& Johnson, 2004; Montgomery et al., 2006) and was beneficial for mental health (Diaz-Caneja \& Johnson, 2004; Montgomery et al., 2006). The sense of reciprocity of their love with their children was seen as an important motivator to remaining on track with treatment and participating actively with it.

\section{Dealing With Difficulties}

The exacerbation of motherhood's challenges by having MD was reported in five studies (Birch et al., 2005; Chernomas et al., 2000; DiazCaneja \& Johnson, 2004; Dipple et al., 2002; Lyon \& Parker, 2003; Montgomery et al., 2006). The symptoms of MD such as depression and mania were seen as impediments for their children's care (DiazCaneja \& Johnson, 2004; Montgomery et al., 2006). Women expressed feelings of anxiety, guilt and apprehension towards the effects of their mental health on their children. Such feelings were associated with the potential of their children being ill, fear of losing their children, and the possible effects of age-inappropriate responsibilities taken by children (Birch et al., 2005; Chernomas et al., 2000; Diaz-Caneja \& Johnson, 2004; Montgomery et al., 2006).

Losing custody of their children was a central apprehension that affected the women (Birch et al., 2005; Chernomas et al., 2000; DiazCaneja \& Johnson, 2004; Dipple et al., 2002; Lyon \& Parker, 2003). Many multi-factorial reasons related to their separation from their children, such as an inadequate care appraisal performed by authorities, women's prolonged hospitalization, and a breakdown in the mother's relationship with the father (Dipple et al., 2002). A major proportion of mothers were separated from their children against their wishes. This experience triggered feelings of anger, frustration, and a deep sense of grief as well as the loss of life purpose (Chernomas et al., 2000; Diaz-Caneja \& Johnson, 2004; Dipple et al., 2002; Lyon \& Parker, 2003).

\section{Beliefs and Attitudes Influenced by Culturally Shaped Gender Roles}

The influence of gender roles and cultural beliefs towards motherhood were reported in four studies (Benders-Hadi et al., 2013; Chernomas et al., 2000; Diaz-Caneja \& Johnson, 2004; Montgomery et al., 2006). Suffering was reported as being caused by the impact of stigma and its close association with the idea that women with SMD are considered bad mothers (Benders-Hadi et al., 2013; Chernomas et al., 2000; Diaz-Caneja \& Johnson, 2004). The suffering with the possibility that their children could be rejected because of their mothers' illness was also reported. The mothers who had lost custody over their children even to relatives or children's fathers also suffered a strong stigma associated with not being able to look after their own children (Diaz-Caneja \& Johnson, 2004; Montgomery et al., 2006).

Mothers have made great efforts to have meaningful relations with their children in the context of illness and suffering. Several strategies, which include making their illness invisible, were adopted by the mothers in order to protect their roles and children. Such strategies were intended to portray the ideal perceptions of mothering prevalent in western culture, which does not include women with SMD (Montgomery et al., 2006).

\section{Dissatisfaction With Healthcare}

Perceptions about healthcare, focusing on the ways in which women experience motherhood were reported in three studies (Chernomas et al., 2000; Diaz-Caneja \& Johnson, 2004; Montgomery et al., 2006).
Lack of interest in approaching parenting issues in health services, lack of acknowledgement of the mothers' difficulties in adhering to treatments and engaging in services, little continuing support in relation to parenting, and limited understanding of mothers' distress and suffering were assessed as negative experiences regarding the provision of healthcare (Montgomery et al., 2006). Due to these barriers, the women's reluctance to disclose their parenting difficulties with healthcare providers was reported (Diaz-Caneja \& Johnson, 2004).

\section{Adoption of Coping Strategies}

\section{Social Support}

The experiences related to social support in the scope of interpersonal relationships, including the interactions with organizations and institutions, were reported in four studies (Manuel et al., 2012; Pickens, 2003; Skärsäter et al., 2003; Sosulski, 2010). The social support received by family members, friends, healthcare providers, church, neighbors, and other patients of psychiatric services influenced the women's ability to cope with the strain of living with SDM. Social support was therefore an important facilitator of community integration (Manuel et al., 2012; Pickens, 2003).

Being together with others, such as family members, friends, and healthcare providers, is a way to improve their sense of self-reliance, to venture outside their homes, and have a meaningful occupation, which may help women to restore their health (Skärsäter et al., 2003; Sosulski, 2010).

\section{Personal Strategies}

The women's personal strategies for dealing with the symptoms of $\mathrm{MD}$, getting well, improving their physical conditions, and releasing emotions and tensions were reported in two studies (Chernomas et al., 2000; Skärsäter et al., 2003). Exercises, massages, positive affirmations, hypnosis, music, reading, painting, and taking vitamins and minerals were considered important measures to cope with depressive symptoms (Skärsäter et al., 2003). Spirituality was seen as a powerful source of strength, often found 'deep within' themselves (Chernomas et al., 2000, p. 12). Creative activities such as writing, cooking, and gardening were perceived as resources to establishing spiritual connections and contributing to their ability to cope with SMD (Chernomas et al., 2000, p. 12).

To be able to leave the depression behind and to start trusting in their own powers of healing are important coping strategies (Skärsäter et al., 2003). Discarding old attitudes and ingrained roles were seen by women as possibilities to finding new ways to access and use the available resources and deal with their daily life (Skärsäter et al., 2003).

\section{DISCUSSION}

Currently, an increase in discussing women's mental health has been seen. Such discussions are not restricted to sexual and reproductive health, but raise awareness of the needs of women with SMD. The promotion of better quality of life and general well-being are essential to provide comprehensive and effective mental healthcare. This is achieved by taking into account the biological social, cultural, economic and personal issues concerned with women's lives (Judd et al., 2009; McKay, 2010; UNFPA, 2008; WHO, 2010a).

Physical and mental health is closely interdependent and intertwined with several psychosocial conditions. SMD exist alongside numerous other demands and challenges in women's lives, and are experienced against a backdrop of violence, lack of safety, unemployment, financial insecurity, and unstable relationships (Carpenter-Song, Holcombe, Torrey, Hipolito, \& Peterson, 2014; Meade \& Sikkema, 2007). Women with SMD are at risk of multiple losses across social, personal and material dimensions, including a loss of roles and relationships, a lack of control over their lives, as well as discrimination, oppression, and reduced choices and opportunities for social interaction (McKay, 2010). 
Women living in developing countries are exposed more frequently to psychosocial risk factors that increase their susceptibility to mental health problems, including the restricted access to mental health services, and the lack of health services to integrating mental and reproductive healthcare (Gaviria \& Rondon, 2010; WHO, 2010a). Although the international community has pledged to address mental health problems focused on women, many women suffer their deleterious effects. The main effects on women with SMD include increased physical illness, risks related to sexual behaviors and substance abuse, unintended pregnancy, and sexually transmitted diseases (UNFPA, 2008).

This review's findings confirmed the existence of strong barriers to offer an appropriate and effective care. Specific factors related to patients and providers act as barriers to address the healthcare needs of women with SMD (De Hert et al., 2011). Many barriers are related to women's attitudes and psychosocial issues, such as difficulties in expressing their health needs, lack of social skills to build constructive relationships, lack of family support, as well as poverty, unequal access to education and work and its benefits, and inadequate provision of reproductive healthcare (De Hert et al., 2011; Gaviria \& Rondon, 2010; Phelan, Stradins, \& Morrison, 2001; Sokal, Messias, Dickerson, et al., 2004). Not being listened to by healthcare providers and the lack of active participation in decisions were the main reasons for women with SMD not to engage in treatment and self-care practices (Priebe, Watts, Chase, \& Matanov, 2005).

Current research has suggested that healthcare providers' erroneous beliefs regarding SMD, such as the view that mentally ill persons are unable to adopt health lifestyles and gain knowledge regarding medical issues, can impair communication with patients (Druss et al., 2010; Parks \& Radke, 2008). Listening to patients carefully in order to identify the women's individual perspectives and providing these supportive and nurture care requirements were considered to be important strategies to empowering them and reducing mental health stigma (Birch et al., 2005; De Hert et al., 2011). Personal and tailored healthcare according to the women's needs and expectations should be provided. Their future goals and hopes require proper recognition by healthcare providers (Davidson \& Roe, 2007; McKay, 2010).

The need to establish a close connection between mental health problems and disability was recommended. Prominent impairments in psychosocial functioning have been observed among the women with SMD. Poor functioning in social relations and the loss of support contribute to increase the women's vulnerability and impinge on women's psychological well-being (Mueser et al., 2010). Women with SMD are subjected to high levels of stigma, discrimination, and exclusion due to widely held misconceptions about the causes and nature of mental health conditions (WHO, 2010b). Stigma provokes harmful consequences for people with SMD and can lead to impoverishment, social marginalization, and low quality of life (Hansson \& Rasmussen, 2014; Thornicroft, Brohan, Rose, Sartorius, \& Leese, 2009). The negative association between stigma and social support and the protective effect of social support in mitigating the negative consequences of stressful events on physical and psychological well-being were confirmed (Ferreira, Silveira, Noto, \& Ronzani, 2014). Stigmatization of people with SMD also lessens the responsiveness of the health services and may cause treatment delays or avoidance (Corrigan, Larson, \& Rüsch, 2009; De Hert et al., 2011).

Women with SMD also experience disturbing experiences regarding sex and sexuality. However, the women's needs in terms of sexuality and intimacy are ignored or inadequately approached by healthcare providers (Matevosyan, 2010). Social stigma impacts upon people with SMD's self-image, making it more difficult for people to have sexual experiences. They do not engage in sexual activity until later in life and do not acquire the knowledge or skills required for the fulfillment of sexual roles and construction of pleasurable sexual relations (Quinn \& Browne, 2009; Volman \& Landeen, 2007). Unsafe sexual behaviors are common among SMD populations, even though such individuals may report sexual disinterest (Scott \& Happell, 2011; Sosulski, 2010).
Evidence has suggest that correlates of sexual risk may differ between men and women, possibly reflecting gender differences in the manifestation of psychiatric illness and medication side-effects. Condom use is a male-controlled practice that may be difficult for women in imbalanced gender relations to negotiate (Meade \& Sikkema, 2007).

Women with SMD experience ambivalent feelings regarding motherhood. Regardless of the circumstances, mothers want to be responsible for their children and recognize the meaningfulness and pleasure concerning mother's roles in their lives. These women's experiences lead to constructive behaviors toward health and improving their engagement in treatment. Family life is also an important context for women's recovery. Motherhood provides opportunities to construct a socially valued identity, and raising children involves routines that impart meaning and give structure to women's daily lives (CarpenterSong et al., 2014).

However, women identified great difficulties in coping with SMD and responding to the demands associated with parenting. A widespread assumption that mentally ill women are inherently poor parents and its associated stigma was seen as affecting children as well as mothers. Women with SMD often parent without adequate support from psychiatric and behavioral health providers. Healthcare facilities were perceived as offering little continuing support in relation to parenting relations, intervening only in crises (Diaz-Caneja \& Johnson, 2004; Maybery \& Reupert, 2009; Montgomery et al., 2006). Rehabilitative efforts tailored for this population should focus on social support for mothers and community integration, taking into account the sociocultural backgrounds, as well as their personal and social needs (Benders-Hadi et al., 2013; Carpenter-Song et al., 2014; Dipple et al., 2002; Montgomery et al., 2006).

The women's strategies for coping with adversity include improving their interpersonal relations, dealing with daily life situations, establishing connections with social supports, and relying on spiritual strength (Chernomas et al., 2000; Manuel et al., 2012; Pickens, 2003; Skärsäter et al., 2003; Sosulski, 2010). As suggested by Chernomas et al. (2000), despite the problems confronted, women conveyed a pervasive and persistent sense of wanting life to improve and hoping that it could. Women also wanted friends, a job, and the energy to make desired things happen and to find some connection to the world in order to have a purpose in life (Chernomas et al., 2000; Pickens, 2003).

The scope and importance of both formal and informal social networks in the daily lives of women with SMD have become clear (Pickens, 2003). Healthcare providers assume an essential role in this area. Women with SMD could be supported by the recognition of these social network resources, and an emphasis on coping strategies should be explored to enable women to deal with difficult situations when confronted with everyday life problems (Pickens, 2003; Skärsäter et al., 2003; Sosulski, 2010). Therefore, women could be engaged in discussions of their options for community integration and treatments available. The adoption of this strategy could bolster the women's capacity for independent decisions and actions, and help them to find jobs, housing, education, and appropriate treatment (Borba et al., 2011; Manuel et al., 2012).

\section{CONCLUSIONS}

This IR study identified the complex experiences lived by women with SMD. The review method enabled the ability to describe the factors influencing the experiences and daily life attitudes of adult women living with SMD in a broader perspective.

The evidence suggested that the experiences and attitudes of women with SMD toward healthcare are influenced by the quality of their relationship with care providers, the barriers to accessing healthcare, the impact of the disorders' symptoms, and the lack of knowledge on women's health issues. Moreover, there are also several other factors associated with their lived experiences, regarding their life circumstances and psychosocial background. 
The social stigma and discrimination suffered by women with SMD contribute to their vulnerabilities toward family members and social integration and hinder their possibilities to make informed choices about health. To change health practices, some researchers have assigned the need to develop health education actions, focused on supporting women to improve skills to deal with social isolation, stigma, discrimination, and racism (Birch et al., 2005; Borba et al., 2011; Nicolaidis et al., 2010; Pickens, 2003). Therefore, the potentialities of health education activities as a successful strategy to promote emancipatory and therapeutic process towards SMD should be addressed. The use of emancipatory strategies contributes to increased awareness, development of autonomy, and enhanced empowerment (Birch et al., 2005; Borba et al., 2011; Diaz-Caneja \& Johnson, 2004; Lyon \& Parker, 2003; Skärsäter et al., 2003). Through empowerment, the possibility of engaging in activities aimed at satisfaction of a woman's own interests and needs is improved (Davidson, DiGiacomo, \& McGrath, 2011; Hoga, Rodolpho, Gonçalves, \& Quirino, 2014).

Motherhood is another factor associated with women's attitudes toward health. As mothers, women have developed strategies influenced by gendered ideals of mothering to deal with difficulties exacerbated by their mental health problems. The need for safe, practical, and emotional support in parenting from family and healthcare providers as a key strategy to overcome the problems encountered in motherhood has become clear. Healthcare providers need to comprehensively assess mentally ill mothers, being sensitive to SMD's motherhood roles (Benders-Hadi et al., 2013; Diaz-Caneja \& Johnson, 2004; Dipple et al., 2002; Montgomery et al., 2006).

This IR highlighted that healthcare providers can better contribute to improving the quality of care for women with SMD, but there are a number of barriers to overcome. Considering the women's subjectivity and promoting a closer integration between mental health treatment/ management and psychosocial factors are essential elements for comprehensive and meaningful care of women with SMD.

The public mental health policy needs to be linked with continuing education for healthcare providers. Training and guidance to healthcare providers should be developed and implemented for assessing and meeting the complex different needs of women with SMD, in order to reducing disparities in mental health and mental healthcare for women. It is important that any public health strategy addresses the systemic aspects of women's mental health, which requires collaboration and integration of knowledge from an interdisciplinary work, including different professionals (Borba et al., 2011; Chernomas et al., 2000; Diaz-Caneja \& Johnson, 2004; Gaviria \& Rondon, 2010).

Further studies are needed to investigate root causes, risks and protective factors across the women's life course (Collins et al., 2011). In this scope, the intersection between SMD and psychosocial factors such as violence, stigma, cultural background, social network, and racism, should be explored (Borba et al., 2011; Manuel et al., 2012; Nicolaidis et al., 2010; Pickens, 2003). More research is also needed to develop and evaluate effectiveness of interventions designed to improve the women's experiences of living with SMD, such as specific psychoeducational programs, treatment options, community resources, and coping strategies (Nicolaidis et al., 2010; Skärsäter et al., 2003; Ward, Clark, \& Heidrich, 2009).

\section{LIMITATIONS}

This IR has limitations regarding the reviewed papers and the review method. The assessment of study quality showed the lack of consistent theoretical underpinning, which may have led to faulty conclusions of the empirical studies due to appropriateness of logical coherence and consistency of terms and relationships (De Kock et al., 2009; Kitson et al., 2008). Therefore, it is necessary to carefully consider the conclusions of our review.

Most of papers included in this IR employed qualitative methods. Nonetheless, there is a possibility that the reported findings may not be representative of the experiences lived by the majority of women with SMD worldwide. Overinterpretation of the findings may be another problem, as even clear conclusions were based on the results from small convenience samples (Sak-Dankosky, Andruszkiewicz, Sherwood, \& Kvist, 2014).

\section{References}

Andrade, L. H. G. S., Viana, M. C., \& Silveira, C. M. (2006). Epidemiology of women's psychiatric disorders. Revista de Psiquiatria Clínica, 33(2), 43-54, http://dx.doi.org/10. 1590/S0101-60832006000200003.

Barnett, I., Guell, C., \& Ogilvie, D. (2012). The experience of physical activity and the transition to retirement: a systematic review and integrative synthesis of qualitative and quantitative evidence. International Journal of Behavioral Nutrition and Physical Activity, 9, 97, http://dx.doi.org/10.1186/1479-5868-9-97.

Benders-Hadi, N., Barber, M., \& Alexander, M. J. (2013). Motherhood in women with serious mental illness. The Psychiatric Quarterly, 84, 65-72, http://dx.doi.org/10.1007/ s11126-012-9227-1.

Birch, S., Lavender, T., \& Cupitt, C. (2005). The physical healthcare experiences of women with mental health problems: Status versus stigma. Journal of Mental Health, 14(1), 61-72.

Borba, C. P. C., DePadilla, L., Druss, B. G., McCarty, F. A., von Esenwein, S. A., \& Sterk, C. E. (2011). A day in the life of women with a serious mental illness: A qualitative investigation. Women's Health Issues, 21(4), 286-292, http://dx.doi.org/10.1016/j.whi. 2010.11.003.

Caldwell, K., Henshaw, L., \& Taylor, G. (2011). Developing a framework for critiquing health research: an early evaluation. Nurse Education Today, 31, e1-e7, http://dx. doi.org/10.1016/j.nedt.2010.11.025.

Carpenter-Song, E. A., Holcombe, B. D., Torrey, J., Hipolito, M. M. S., \& Peterson, L. D. (2014). Recovery in a family context: experiences of mothers with serious mental illnesses. PRJ [Internet], http://dx.doi.org/10.1037/prj0000041 (cited 2014 Aug 28 Available from:).

Chernomas, W. M., Clarke, D. E., \& Chisholm, F. A. (2000). Perspectives of women living with schizophrenia. Psychiatric Services, 51, 1517-1521, http://dx.doi.org/10.1176/ appi.ps.51.12.1517.

Collins, P. Y., Patel, V., Joestl, S. S., March, D., Insel, R., \& Daar, A. S. (2011). Grand challenges in global mental health. Nature, 475(7354), 27-30, http://dx.doi.org/10.103/475027a.

Corrigan, P. W., Larson, J. E., \& Rüsch, N. (2009). Self-stigma and the "why try" effect: impact on life goals and evidence-based practices. World Psychiatry, 8, 75-81.

Davidson, M. (2012). A Nurse's Guide to Women's Mental Health. New York, NY: Springer Publishing Company

Davidson, P., DiGiacomo, M., \& McGrath, S. (2011). The feminization of aging: how will this impact on health outcomes and services? Health Care for Women International, 32, 1031-1045, http://dx.doi.org/10.1080/07399332.2011.610539.

Davidson, L., \& Roe, D. (2007). Recovery from versus recovery in serious mental illness: one strategy for lessening confusion plaguing recovery. Journal of Mental Health, 16(4), 459-470, http://dx.doi.org/10.1080/09638230701482394.

De Hert, M., Cohen, D., Bobes, J., Cetkovich-Bakmas, M., Leucht, S., Ndetei, D. M., et al. (2011). Physical illness in patients with severe mental disorders. II. Barriers to care, monitoring and treatment guidelines, plus recommendations at the system and individual level. World Psychiatry, 10(2), 138-151.

De Kock, E., van Biljon, J., Pretorius, M., De Kock, E., van Biljon, J., \& Pretorius, M. (2009) Usability evaluation methods: Mind the gaps. The Annual Research Conference of the South African Institute of Computer Scientists and Information Technologists, 2009, Riverside, Vanderbijlpark. Proceedings. (pp. 122-131), http://dx.doi.org/10.1145/1632149. 1632166.

Diaz-Caneja, A., \& Johnson, S. (2004). The views and experiences of severely mentally ill mothers: a qualitative study. Social Psychiatry and Psychiatric Epidemiology, 39, 472-482, http://dx.doi.org/10.1007/s00127-004-0772-2.

Dipple, H., Smith, S., Harry, H., \& Evans, B. (2002). The experience of motherhood in women with severe and enduring mental illness. Social Psychiatry and Psychiatric Epidemiology, 37, 336-340, http://dx.doi.org/10.1007/s00127-002-0559-2.

Drake, R. E., O'Neal, E. L., \& Wallach, M. A. (2008). A systematic review of psychosocial research on psychosocial interventions for people with co-occurring severe mental and substance use disorders. Journal of Substance Abuse Treatment, 34, 123-138, http://dx. doi.org/10.1016/j.jsat.2007.01.011.

Druss, B. G., von Esenwein, S. A., Compton, M. T., Rask, K. J., Zhao, L., \& Parker, R. M. (2010) A randomized trial of medical care management for community mental health settings: the Primary Care Access, Referral, and Evaluation (PCARE) study. The American Journal of Psychiatry, 167, 151-159, http://dx.doi.org/10.1176/appi.ajp. 2009.09050691.

Ferreira, G. C. L., Silveira, P. S., Noto, A. R., \& Ronzani, T. M. (2014). Estudos de Psicologia 19(1), 77-86, http://dx.doi.org/10.1590/S1413-294X2014000100010 (Available from:).

Gaviria, S. L., \& Rondon, M. B. (2010). Some considerations on women's mental health in Latin America and the Caribbean. International Review of Psychiatry, 22(4), 363-369, http://dx.doi.org/10.3109/09540261.2010.500868.

Hansson, L. M., \& Rasmussen, F. (2014). Association between perceived health care stigmatization and BMI change. Obesity Facts, 7(3), 211-220, http://dx.doi.org/10.1159/ 000363557.

Hoga, L. A. K., Rodolpho, J. R. C., Gonçalves, B. G., \& Quirino, B. C. (2014). Women's experiences of menopause: a systematic review protocol of qualitative evidence. The JB Database of Systematic Reviews and Implementation Reports, 12(7), 72-81.

Judd, F., Armstrong, S., \& Kulkarni, J. (2009). Gender-sensitive and mental health care. Australasian Psychiatry, 17, 105-111, http://dx.doi.org/10.1080/10398560802596108. 
Kitson, A. L., Rycroft-Malone, J., Harvey, G., McCormack, B., Seers, K., \& Titchen, A. (2008). Evaluating the successful implementation of evidence into practice using the PARiHS framework: theoretical and practical challenges. Implementation Science, 3(1), 1-12, http://dx.doi.org/10.1186/1748-5908-3-1.

Kohn, R., \& Rodriguez, J. (2009). Prevalencia y carga de los trastornos mentales en la poblacion adulta de America Latina y el Caribe. In J. Rodríguez, R.. Kohn, \& S. Aguilar-Gaxiola (Eds.), Epidemiologia de los Trastornos Mentales en America Latina y el Caribe (pp. 19-32). Washington DC: Pan American Health Organization.

Lyon, D., \& Parker, B. (2003). Gender-related concerns of rural women with severe and persistent mental illnesses. Archives of Psychiatric Nursing, 17(1), 27-32, http://dx. doi.org/10.1053/apnu.2003.3.

Manuel, J. I., Hinterland, K., Conover, S., \& Herman, D. B. (2012). "I hope I can make it out there": Perceptions of women with severe mental illness on the transition from hospital to community. Community Mental Health Journal, 48, 302-308, http://dx.doi.org/ 10.1007/s10597-011-9442-5

Matevosyan, N. R. (2010). Evaluation of perceived sexual functioning in women with serious mental illnesses. Sexuality and Disability, 28, 233-243, http://dx.doi.org/10. 1007/s11195-010-9166-4.

Maybery, D., \& Reupert, A.. (2009). Parental mental illness: a review of barriers and issues for working with families and children. Journal of Psychiatric and Mental Health Nursing, 16(9), 784-791, http://dx.doi.org/10.1111/j.1365-2850.2009.01456.x.

Mays, N., Pope, C., \& Popay, J. (2005). Systematically reviewing qualitative and quantitative evidence to inform management and policy-making in the health field. Journal of Health Services Research \& Policy, 10, 6-20, http://dx.doi.org/10.1258/ 1355819054308576.

McKay, E. A. (2010). 'Rip that book up, I've changed': unveiling the experiences of women living with and surviving enduring mental illness. British Journal of Occupational Therapy, 73(3), 96-105, http://dx.doi.org/10.4276/030802210X12682330090370.

Meade, C. S., \& Sikkema, K. J. (2007). Psychiatric and psychosocial correlates of sexual risk behavior among adults with severe mental illness. Community Mental Health Journal, 43(2), 153-169, http://dx.doi.org/10.1007/s10597-006-9071-6.

Montgomery, P., Tompkins, C., Forchuk, C., \& French, S. (2006). Keeping close: mothering with serious mental illness. Journal of Advanced Nursing, 54(1), 20-28, http://dx.doi. org/10.1111/j.1365-2648.2006.03785.x.

Mueser, K. T., Pratt, S. I., Bartels, S. J., Swain, K., Forester, B., Cather, C., et al. (2010). Randomized trial of social rehabilitation and integrated health care for older people with severe mental illness. Journal of Consulting and Clinical Psychology, 78(4), 561-573, http://dx.doi.org/10.1037/a0019629.

Nicolaidis, C., Timmons, V., Thomas, M. J., Star Waters, A., Wahab, S., Mejia, A., et al. (2010). "You don't go tell white people nothing": African American women's perspectives on the influence of violence and race on depression and depression care. American Journal of Public Health, 100(8), 1470-1476, http://dx.doi.org/10.2105/ AJPH.2009.161950.

Parks, J., \& Radke, A. Q. (Eds.). (2008). Obesity reduction and prevention strategies for individuals with serious mental illness. Alexandria: National Association of State Mental Health Program Directors (NASMHPD), Medical Directors Council.

Pearson, A., White, H., Bath-Hextall, F., Apostolo, J., Salmond, S., \& Kirkpatrick, P. (2014). The Joanna Briggs Institute Reviewers' Manual 2014. Methodology for JBI MixedMethods Systematic Reviews. Adelaide: The Joanna Briggs Institute (Available from: http://www.joannabriggs.org/assets/docs/sumari/ReviewersManual_MixedMethods-Review-Methods-2014-ch1.pdf, accessed 13 February 2015)

Phelan, M., Stradins, L., \& Morrison, S. (2001). Physical health of people with severe mental illness. BMJ, 322, 443-444, http://dx.doi.org/10.1136/bmj.322.7284.443 (Internet, cited 21 Jul 2014, Available from:).

Pickens, J. M. (2003). Formal and informal social networks of women with serious mental illness. Issues in Mental Health Nursing, 24, 109-127, http://dx.doi.org/10.1080/ 01612840390160676.

Priebe, S., Watts, J., Chase, M., \& Matanov, A. (2005). Processes of disengagement and engagement in assertive outreach patients: qualitative study. British Journal of Psychiatry, 187, 438-443, http://dx.doi.org/10.1192/bjp.187.5.438.

Quinn, C., \& Browne, G. (2009). Sexuality of people living with a mental illness: A collaborative challenge for mental health nurses. International Journal of Mental Health Nursing, 18, 195-203, http://dx.doi.org/10.1111/j.1447 0349.2009.00598.x.

Sajatovic, M., Friedman, S. H., Schuermeyer, I. N., Safavi, R., Ignacio, R. V., Hays, R. W., et al. (2006). Menopause knowledge and subjective experience among peri- and postmenopausal women with bipolar disorder, schizophrenia and major depression. Journal of Nervous and Mental Disease, 194(3), 173-178, http://dx.doi.org/10.1097/01.nmd. 0000202479.00623 .86

Sak-Dankosky, N., Andruszkiewicz, P., Sherwood, P. R., \& Kvist, T. (2014). Integrative review: nurses' and physicians' experiences and attitudes towards inpatient- witnessed resuscitation of an adult patient. Journal of Advanced Nursing, 70(5), 957-974, http://dx.doi.org/10.1111/jan.12276.

Scott, D., \& Happell, B. (2011). The high prevalence of poor physical health and unhealthy lifestyle behaviours in individuals with severe mental illness. Issues in Mental Health Nursing, 32(9), 589-597, http://dx.doi.org/10.3109/01612840.2011.569846.

Skärsäter, I., Dencker, K., Bergbom, I., Häggström, L., \& Fridlund, B. (2003). Women's conceptions of coping with major depression in daily life: a qualitative, salutogenic approach. Issues in Mental Health Nursing, 24(4), 419-439, http://dx.doi.org/10.1080/ 01612840390212632.

Soares, M. V. B., \& Carvalho, A. M. P. (2009). Women with mental disorders and motherhood. Revista Latino-Americana de Enfermagem, 17(5), 632-638, http://dx.doi.org/10. 1590/S0104-11692009000500006.

Soares, C. B., Hoga, L. A. K., Peduzzi, M., Sangaleti, C., Yonekura, T., \& Silva, D. R. A. D. (2014). Integrative review: concepts and methods used in nursing. Revista da Escola de Enfermagem da U S P, 48(2), 329-339, http://dx.doi.org/10.1590/s0080623420140000200020

Sokal, J., Messias, E., Dickerson, F. B., Kreyenbuhl, J., Brown, C. H., Goldberg, R. W., et al. (2004). Comorbidity of medical illnesses among adults with serious mental illness who are receiving community psychiatric services. Journal of Nervous and Mental Disease, 192, 421-427 (Internet, cited 21 Fev 2013, Available from: http://www.ncbi.nlm.nih.gov/pubmed/?term= Comorbidity + of + medical + illnesses + among + adults + with + serious + mental + illness + who+are+receiving + community + psychiatric + services).

Sosulski, M. R. (2010). Life history and narrative analysis: Feminist methodologies contextualizing Black women's experiences with severe mental illness. Journal of Sociology and Social Welfare, 37(3), 29-57 (Internet, cited 2011 Mar 16, Available from: http://wmich.edu/hhs/newsletters_journals/jssw_institutional/institutional_ subscribers/37.3.Sosulski.pdf).

Thornicroft, G., Brohan, E., Rose, D., Sartorius, N., \& Leese, M. (2009). Global pattern of experienced and anticipated discrimination against people with schizophrenia: a crosssectional survey. Lancet, 373(9661), 408-415, http://dx.doi.org/10.1016/S01406736(08)61817-6.

U.S. Department of Health, \& Substance Abuse \& Mental Health Services Administration (2012). Results from the 2012 National Survey on Drug Use and Health: Mental Health Findings. (Internet, Available from: http://www.samhsa.gov/data/NSDUH/2k12MH FindingsandDetTables/2K12MHF/NSDUHmhfr2012.htm, accessed 13 June 2014).

United Nations Population Fund (2008). UNFPA Emerging issues: Mental, sexual and reproductive health. (New York, Available from: http://www.unfpa.org/webdav/ site/global/shared/documents/publications/2008/mental_rh_eng.pdf, accessed 08 August 2014).

Volman, L., \& Landeen, J. (2007). Uncovering the sexual self in people with schizophrenia. Journal of Psychiatric and Mental Health Nursing, 14(4), 411-417, http://dx.doi.org/10. 1111/j.1365-2850.2007.01099.x

Ward, E. C., Clark, L. O., \& Heidrich, S. (2009). African American women's beliefs, coping behaviors, and barriers to seeking mental health services. Qualitative Health Research, 19(11), 1589-1601, http://dx.doi.org/10.1177/1049732309350686.

Whittemore, R. (2005). Analysis of integration in nursing science and practice. Journal of Nursing Scholarship, 37, 261-267, http://dx.doi.org/10.1111/j.1547-5069.2005.00045.x.

Whittemore, R., \& Knafl, K. (2005). The integrative review: updated methodology. Journal of Advanced Nursing, 52, 546-553, http://dx.doi.org/10.1111/j.1365-2648.2005.03621.x.

World Health Organization (2001). The World Health Report 2001. Mental Health: New understanding, new Hope (Geneva, Available from: http://www.who.int/whr/2001/ en/whr01_en.pdf?ua=1, accessed 02 October 2014).

World Health Organization (2006). Gender disparities in mental health. (Geneva, Available from: http://www.who.int/mental_health/media/en/242.pdf, accessed 13 June 2014).

World Health Organization (2010a). Mental health and development: Integrating mental health into all development efforts including MDGs. (Geneva, Available from: http:// www.who.int/mental_health/policy/mhtargeting/mh_policyanalysis_who_undesa. pdf, accessed 07 July 2014)

World Health Organization (2010b). Mental health and development: Targeting people with mental health conditions as a vulnerable group. (Geneva, Available from: http:// whqlibdoc.who.int/publications/2010/9789241563949_eng.pdf?ua=1, accessed 20 May 2014).

World Health Organization (2013). Mental Health Action Plan 2013-2020. (Geneva, Available from: http://apps.who.int/iris/bitstream/10665/89966/1/9789241506021_eng. pdf?ua $=1$, accessed 07 July 2014).

World Health Organization (2014). Social determinants of mental health. (Geneva, Available from: http://apps.who.int/iris/bitstream/10665/112828/1/9789241506809_eng. pdf?ua $=1$, accessed 07 July 2014). 